\title{
RESPONSIBILITY AS A DETERMINANT OF THE ACTIVITY OF CONTEMPORARY ENTREPRENEURS
}

The article shows selected results of empirical research. The state of knowledge on CSR in society among business faculty students in Podkarpacie was presented on its base. The aim of the research was to learn about the attitudes and opinions of young, potential managers (graduating from this field) about their awareness of CSR activities in Poland.

CSR is a current theme which is widely discussed in the area of management. The salience of this concept may be demonstrated by the fact that it is taken into account in the development of business models of modern enterprises.

The first part of the article presents the theoretical foundations for the principles of corporate social responsibility. It addresses the question of the essence of corporate social responsibility. CSR was described as the art of managing modern enterprises, which put a considerable emphasis on this aspect, since they are aware of the role of establishing relationships with stakeholders. Stakeholders are a key concept when it comes to undertaking business activities in the area of corporate social responsibility.

The second part of the study presents the results of the research carried out among finalyear students from the Faculty of Management at the Rzeszów University of Technology.

CSR is a challenging path, but it may bring long-lasting benefits. It changes business paradigms, rediscovering and emphasizing the importance of relationships between the organisation and its surroundings. It is a modern model of managing an organization that facilitates its operation on a competitive market and simultaneously increases the company's innovativeness.

The principles of CSR are simple: honesty, reliability, sensitivity, loyalty, righteousness. These values cannot be purchased, it takes years to develop them, and they are becoming a valuable resource in the modern economy.

Keywords: CSR, relationship management, company stakeholders, responsibility.

\footnotetext{
${ }^{1}$ Hanna Sommer PhD, Assistant Professor, Rzeszów University of Technology, Faculty of Management, Department of Humanities; ul. Podkarpacka 1,35-959 Rzeszów; e-mail: hansom@ prz.edu.pl. ORCID: 0000-0001-7208-7641.

${ }^{2}$ Grzegorz Zakrzewski PhD, Eng., University of Security in Poznan, ul. Marynarki Polskiej 15, 80-557 Gdańsk e-mail: grzegorz.zakrzewski@wsb.net.pl. ORCID: 0000-0002-0945-5322.
} 


\section{INTRODUCTION}

Over the centuries, views related to the functions that enterprises should perform have changed. In terms of the classic approach, the company's priority should be to maximize profit. However, with time, these issues started to be perceived somewhat differently. Attempts were made to encourage economic entities to not only achieve its business goals but also to contribute to the growth of social wealth. Attempts were made to involve enterprises in social issues in the field of corporate social responsibility (CSR).

The CSR concept was created in the 1960s in the United States. The growing competitive advantage of the USA meant that this concept began to attract a broad group of supporters in Europe as well. The process of globalization, visible in every sphere of economic life, was also of great importance for the interest CSR.

The modern and simultaneously responsible business is constantly looking for synergy between economic, social and environmental aspects. Large, international corporations are doing a lot to be perceived as responsible. They want to be well-perceived both by their consumers, as well as by non-governmental organizations. CSR is not applicable solely to large companies. Small and medium-sized enterprises that play an important role in the development of local communities and are not always aware of their CSR potential are also increasingly observable.

In Poland, during the transformation period, an argument was often used that the economy is not fully mature for it to be able to take into account social and environmental issues, and companies are forced to fight for survival in the market.

Corporate social responsibility has been seen in a rather peculiar way in Poland thus far. Usually social responsibility has been discussed in the context of financial donations supporting a good cause or social campaign. These discussions were accompanied by assurances regarding the selflessness of these actions. But after all the management theory defines corporate social responsibility as a modern instrument to build the company's value and leverage. This kind of charity actions could be, at most, a form of redistribution of elaborated profits (Rok, 2012).

However, the relatively high economic growth observed in recent years and the current economic crisis should encourage enterprises to change their management model to a more responsible one. These are the activities in which a business should seek its competitive advantage in the market.

\section{THE ESSENCE OF CORPORATE SOCIAL RESPONSIBILITY}

The concept of corporate social responsibility is a broad and complex issue. A clear definition of the scope and type of socially responsible activities cannot be offered. A lot in this respect depends on the local culture, the industry in which the company operates, but also on the development of the country and the growth of social awareness. Some theoreticians pay attention to the voluntary nature of the company's activities, for others, it is important to build positive relationships with stakeholders. The moment when the company should make the decision to conduct activities for the benefit of the society is also an important issue. Should it be done at the very beginning of its business activity or only when it has achieved a suitable position on the market and has guaranteed adequate profits.

A new moral contract between society and corporate organisations is based on linking corporate economic success with social and economic development which is enhancing 
social welfare. Therefore, corporations should be creating values instead of only picking them up (Paliwoda-Matiolańska, 2014).

The most comprehensive view is presented in Gasparski's definition, according to whom, a responsible business should increase the company's value over a longer period of time, ensure proper relationships with the company's stakeholders, and should oblige to act in accordance with the law and socially established ethical standards (Rok, 2008).

While analysing the concept of social responsibility it is worth to point on the broad range of responsible actions which corporations may take. R. Spearman has extracted five main areas of corporate social responsibility (Grudzewski, Hejduk, Sankowska, Wańtuchowicz, 2009):

1) elimination or weakening of conflicts of interests resulting from the diastase of objective and subjective goals;

2) securing the workers' satisfaction with the results of their work;

3) caring for the wellbeing of the own society;

4) protection of the environment from destruction and leaving it to future generation in a state that allows humans to continue living worthily;

5) caring for the wellbeing of humanity.

An important document detailing CSR was the Davos Manifesto, which stated that management should serve clients as well as co-workers, investors and the whole society, but also balance the different interests of these groups (Rojek-Nowosielska, 2006).

One of the first scientists to pay attention to different types of organizational responsibility was Archie Carroll. He called this distinction the pyramid of corporate social responsibility.

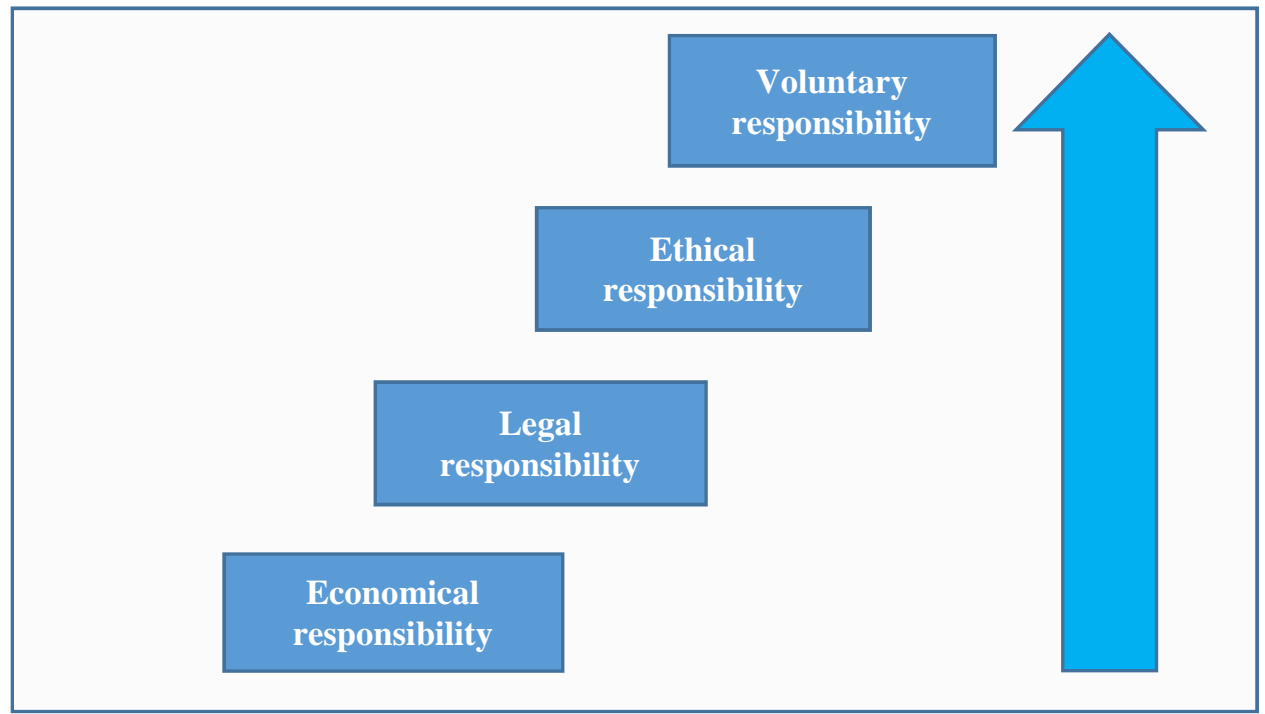

Fig. 1. Pyramid of Corporate Social Responsibility

Source: www.csr.szczecin.pl/baza-wiedzy/czym-jest-csr. 
- The company's economic responsibility refers to the return on the investment that the owners have made.

- An important element of obtaining economic benefits is the legal responsibility and the obligation to act within its boundaries.

- The company has a duty to act in accordance with the ethical standards adopted in society.

- Companies have a discretionary responsibility, exhibiting behaviours that can help both the company and the public (www.csr.szczecin.pl/baza-wiedzy/czych-jest-csr).

Corporate social responsibility is described in various ways. This issue is discussed by many different scientific disciplines and each of them offers a different perspective and new conclusions related to social responsibility.

All the definitions of CSR, irrespective of their origin, agree on several aspects:

- compliance with stricter requirements than those contained in legal regulations;

- taking into account the business objectives of the company;

- taking into account the interests of the environment in its activities.

The idea of corporate social responsibility is subject to constant evolution. However, it might be said that it is based on the fact that a company strives to achieve its goals, taking into account the expectations of its employees, customers, local communities, etc.

\section{CSR AS THE ART OF MANAGEMENT}

One can speak about the modern understanding of CSR from 1953, when H.R. Bowen introduced the term "social responsibility". At that time, and for a long time later, it was thought that social responsibility is an attribute of the entrepreneur, and not as it is nowadays - of the organization.

Davis claims that social responsibility grows from the society's strength and corporations should work like a bidirectional open system aimed at signals from society's site and openly, publically revealing its work (Roszkowska, 2011).

Adamczyk (2009) claims among other things: "Corporate social responsibility might be interpreted as a commitment to act transparently and ethically in accordance with sustainable growth and the pursuance of social wealth considering the stakeholders' expectations, but in accordance with the law and norms of acting".

The results of scientific research clearly indicate that CSR is of key importance for the company's stability over a long period of time. Business ethics and the implementation of CSR principles in a comprehensive manner in all areas of the company is an important element in building its sustainable value and advantage in the market.

The benefits of implementing corporate responsibility strategies should be considered in the long term. These are the following (www.csr.szczecin.pl/baza-wiedzy/czych-jestcsr):

- Influencing the loyalty of consumers and stakeholders;

- Correct relationships with the community and local authorities;

- Influencing the level of organizational culture;

- creating a positive image of the company;

- Securing the best employees;

- An increase in the company's competitiveness;

- An increase in the interest of contractors and investors; 
- Employees' interest in taking up employment with a socially responsible employer;

- An improvement in the company's reputation and image;

- Development of the company;

- An increase in pro-ecological activities.

One of the basic principles of effective company management is shaping long-term relationships based on cooperation. Each company enters into various types of relationships with various organizations and individuals. Social responsibility management is a form of seeking a balance between its effectiveness and profitability and a broadly understood social interest.

It might be said that corporate responsibility is an effective management strategy which, when conducting a social dialogue at the local level, increases the competitiveness of companies in the global area, while at the same time shaping good conditions for economic and social development (gap.uek.krakow.pl/images/dokumenty_sympozja/odpbiz.pdf.) Such activities should benefit everyone.

\section{MANAGING RELATIONSHIPS WITH STAKEHOLDERS}

The contemporary reality of business operations is becoming more and more complex. Good relationships with customers are not enough to be competitive. In order to survive in today's market, a company has to establish relationships with a wide range of stakeholders. Therefore, companies which are aware of the role of such relationships considerable emphasis on building proper relationships with broadly understood stakeholders, because they see the benefits that result from proper management of these relations.

Each company, as well as various institutions (e.g. public administration units, nongovernmental organizations, etc.), have their stakeholders because none of them operates in a vacuum and is always either influenced by or influences other entities.

In case a corporation undertakes socially responsible actions the corporation, being a collection of a certain people, undertakes the realisation of a specific vision and afterwards the motivation arises to act on certain goals and specific tasks assigned to both internal and external stakeholders (Bartkowiak, 2011).

Stakeholders are a key concept when taking actions in the field of corporate social responsibility. The European Commission defines CSR as "the responsibility of enterprises for their impact on society" and postulates that "enterprises should have in place a process to integrate social, environmental, ethical, human rights and consumer concerns into their business operations and core strategy in close collaboration with their stakeholders (http://odpowiedzialnybiznes.pl/hasla-encyklopedii/interesariusze/).

The classification of stakeholders can take place according to various criteria (e.g. due to the degree of relevance to the company, the strength of impact or the nature of the relationship, etc.) The basic division concerns internal and external stakeholders.

Internal stakeholders may include (http://odpowiedzialnybiznes.pl/hasla-encyklopedii/ interesariusze/):

- employees;

- shareholders;

- Supervisory Boards.

External stakeholders may include (http://odpowiedzialnybiznes.pl/hasla-encyklopedii/ interesariusze/):

- customers; 
- suppliers;

- competitors;

- state authorities;

- the media;

- trade unions;

- non-governmental organisations;

The issue of stakeholders is very important for corporate social responsibility because it draws attention to both the interest of the owners as well as the broader social interest, whose inclusion affects the sustainable development of the organisation.

Skillful management of relationships with stakeholders may contribute to benefiting the company. The first stage of managing these relations should be their correct identification. This may be achieved by assigning one of two values to all the company's stakeholders:

- Stakeholders who have a large or small influence on the company;

- Stakeholders who are interested or uninterested in the company's activities.

Table 1. Relationship management model

\begin{tabular}{|c|c|}
\hline \multicolumn{2}{|c|}{ Planning } \\
\hline Preliminary stage & Executive stage \\
\hline $\begin{array}{l}\text { - reflection on the role of relationships; } \\
\text { - analysis of the company's potential; } \\
\text { - possibilities of adapting the concept }\end{array}$ & $\begin{array}{l}\text { - internal and inter-organizational arrangements; } \\
\text { - conditions for the activation of relationships; } \\
\text { - evaluation }\end{array}$ \\
\hline \multicolumn{2}{|c|}{ 2. ORGANIZING } \\
\hline Preliminary stage & Executive stage \\
\hline $\begin{array}{l}\text { - selection of entities and forms of cooperation; } \\
\text { - establishing cooperation; } \\
\text { - designing information and decision-making } \\
\text { systems }\end{array}$ & $\begin{array}{l}\text { - coordination in the area of processes, structures } \\
\text { and strategies; } \\
\text { - solidifying cooperation; } \\
\text { - evaluation }\end{array}$ \\
\hline \multicolumn{2}{|c|}{ 3. MOTIVATION } \\
\hline Preliminary stage & Executive stage \\
\hline $\begin{array}{l}\text { - development of an incentive system; } \\
\text { - identification of incentives }\end{array}$ & $\begin{array}{l}\text { - exchange of information and experiences; } \\
\text { - a system of relationship values and norms; } \\
\text { - implementation of the incentive system; } \\
\text { - evaluation }\end{array}$ \\
\hline \multicolumn{2}{|c|}{ 4. CONTROLLING } \\
\hline Preliminary stage & Executive stage \\
\hline $\begin{array}{l}\text { - expected condition of a relationship; } \\
\text { - evaluation indicators; } \\
\text { - monitoring; } \\
\text { - possible event scenarios; }\end{array}$ & $\begin{array}{l}\text { - ongoing assessment of relationship conditions; } \\
\text { - analysis of variations; } \\
\text { - perfecting solutions; } \\
\text { - evaluation }\end{array}$ \\
\hline
\end{tabular}

Source: study based on (Danielak, 2012).

Identifying and classifying stakeholders in terms of impact and interest allows one to take appropriate actions. Precise identification of key stakeholders is important in order to 
effectively involve them in the company's operations. Four basic forms of engaging stakeholders may be distinguished as (http://odpowiedzialnybiznes.pl/artykuly/zarzadzanie-relacje-z-interesariuszami-jako-jeden-z-elementow-spolecznej-odpowiedzialnosci-biznesu/):

- Communication;

- Consulting sessions;

- Partnerships;

- Dialogue.

The management of relationships with stakeholders is a complicated and complex process that requires various activities with regard to planning, organizing, motivating or controlling (tab. 1).

The activities presented in Table 3 are coupled together. Valuable relationships allow the company's stakeholders to obtain a satisfactory added value.

\section{RESULTS OF CONDUCTED STUDIES}

The aim of the research was to learn about the attitudes and opinions of young, potential managers (graduating from this field) about their awareness of CSR activities in Poland. How are CSR activities understood and what are their benefits? Do people pay attention whether a company is socially responsible while making purchasing decisions? Is government and society trying to move the costs of social problems costs into the business area?

The research, whose results are presented in this study was carried out at the turn of March and April 2018 among the students of the Rzeszów University of Technology in the field of Management and specialization of a professional manager. 60 students who were completing the last semester of part-time studies were examined - 36 women and 24 men. 16 people living in the countryside, 32 in the city with less than 100,000 inhabitants and 12 people in a city with more than 100,000 inhabitants. All respondents live in Podkarpackie Voivodeship.

Table 2. Respondents' gender and place of residence

\begin{tabular}{|c|c|c|c|c|c|c|c|c|c|}
\hline \multicolumn{2}{|c|}{} & \multicolumn{3}{|c|}{ MEN } & \multicolumn{2}{c|}{$\begin{array}{c}\text { City over } \\
100,000 \\
\text { inhabitants }\end{array}$} & \multicolumn{2}{c|}{$\begin{array}{c}\text { City of up to } \\
100,000 \\
\text { inhabitants }\end{array}$} & \multicolumn{2}{c|}{ Countryside } \\
\hline N & $\%$ & N & $\%$ & N & $\%$ & N & $\%$ & N & $\%$ \\
\hline 36 & 60 & 24 & 40 & 12 & 20 & 32 & 53 & 16 & 27 \\
\hline
\end{tabular}

Source: own research.

For the most part, they were young people who are in the process of looking for or changing their job, as well as those who have recently taken up work. The method used to carry out the research was the method of a diagnostic survey, which allows to gather personal opinions on the analysed issue. The applied research technique consisted of a questionnaire form completed by the students. As many as $80 \%$ of the surveyed students described themselves as responsible consumers. This manifests itself primarily in making thoughtful purchases like purchasing only necessary products. It is worth noting that slightly more than $6 \%$ of the respondents who had found themselves to be responsible consumers admitted buying products from companies acting ethically.

Selected research results are presented on charts. 


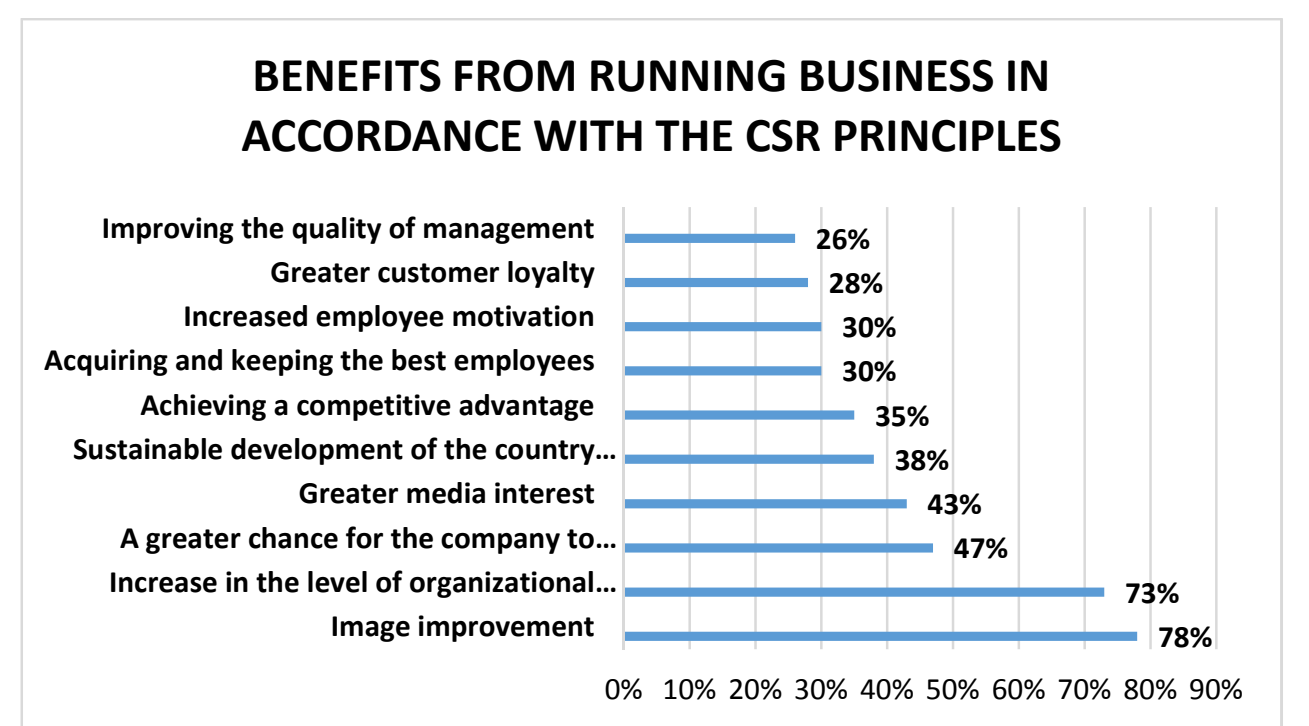

Chart 1. Benefits from running business in accordance with the CSR principles

Source: own research.

Chart 1 illustrates the benefits of carrying out activities in line with the principles of corporate social responsibility. The largest percentage of respondents indicated an improvement in the organization's image (78\%) and an increase in the level of organizational culture $(73 \%)$. The following benefits were indicated to an average degree: a greater chance for the company to stay on the market (47\%), greater media interest (43\%), balanced development of the country and the region (38\%) and achievement of a competitive advantage (35\%). The remaining indicated benefits were also highly rated among the respondents: attracting and retaining the best employees, as well as increasing their motivation (30\%), greater customer loyalty $(28 \%)$ and improvement in the quality of management $(26 \%)$. It might be said that respondents see very large benefits resulting from activities based on the principles of corporate social responsibility. The results of the survey confirmed the conclusions from the discussion which state that generating the company's economic value by means of generating its social value constitutes a mutual benefit for both the company and the society.

As shown by the studies, people entering the labour market pay most attention to the media image of the company $(78 \%)$, the issue of cooperating with social organizations $(72 \%)$ is also important to them. Another factor they attach importance to is whether the organisation participates in pro-environmental campaigns (57\%) and supports for local initiatives $(45 \%)$. A quarter of respondents also pointed to some other aspects that are important for new employees. 


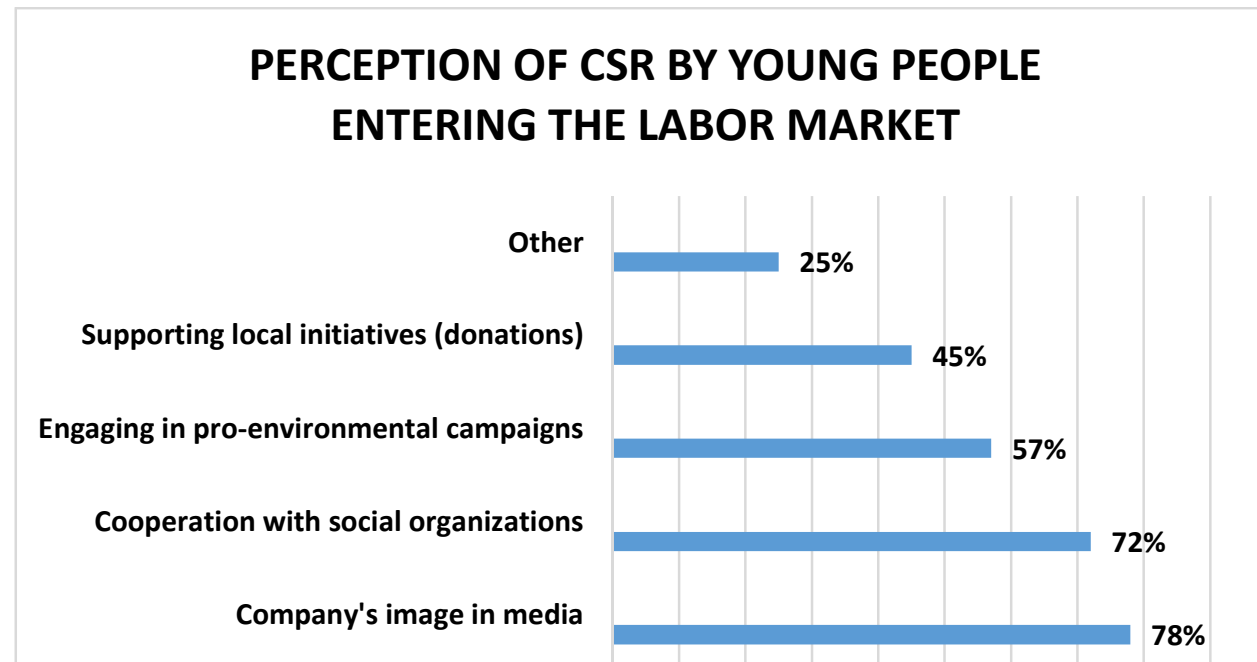

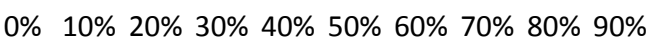

Chart 2. Perception of CSR by young people entering the labor market

Source: own research.

\section{IS GOVERNMENT AND SOCIETY TRYING TO MOVE THE COSTS OF SOCIAL PROBLEMS COSTS INTO THE BUSINESS AREA?}

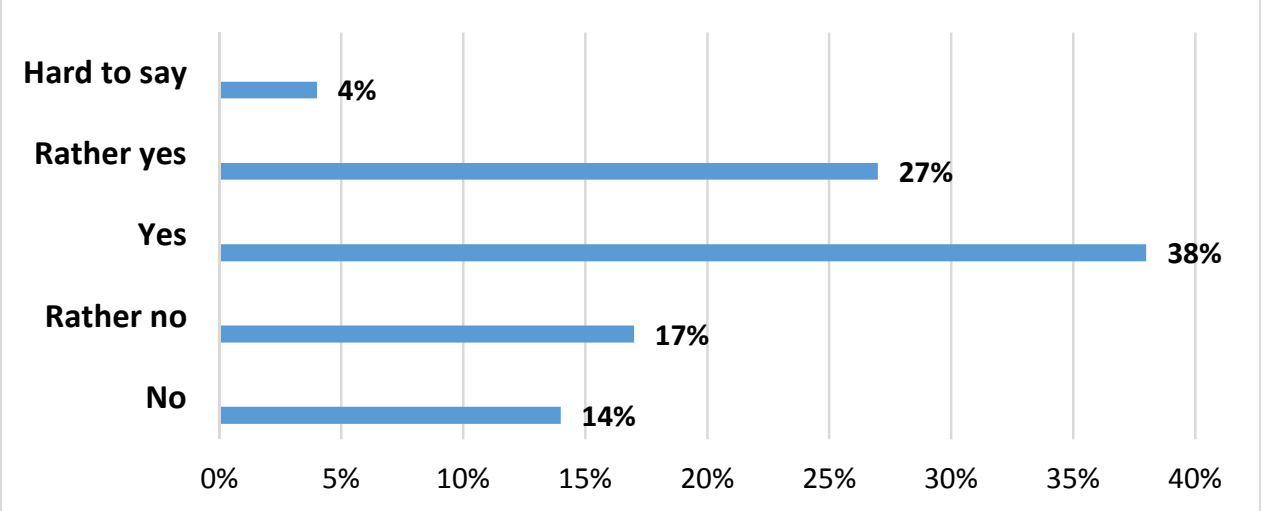

Chart 3. Is government and society trying to move the costs of social problems costs into the business area?

Source: own research. 
The image of companies translates into the attitude towards the products and services offered by a given company. It may be concluded that enterprises which aim to meet market requirements must take into account the issues of corporate social responsibility in their activities. Nowadays, CSR is not merely a matter of choice, it is a necessity.

It is difficult for the respondents to give a definitive opinion on the fact that the government and society are making companies bear the costs of solving social problems (chart 3). Despite the fact that the answers "yes" (38\%) and "rather yes" (27\%) clearly predominate, there is also a significant number of respondents who disagree with this statement (rather no $-17 \%$ and no $-14 \%$ ). Additionally, some of the respondents were not able to take a stand on the analysed issue (4\%).

\section{DECLARATIONS OF PURCHASING PRODUCTS FROM SOCIALLY ENGAGED COMPANIES}

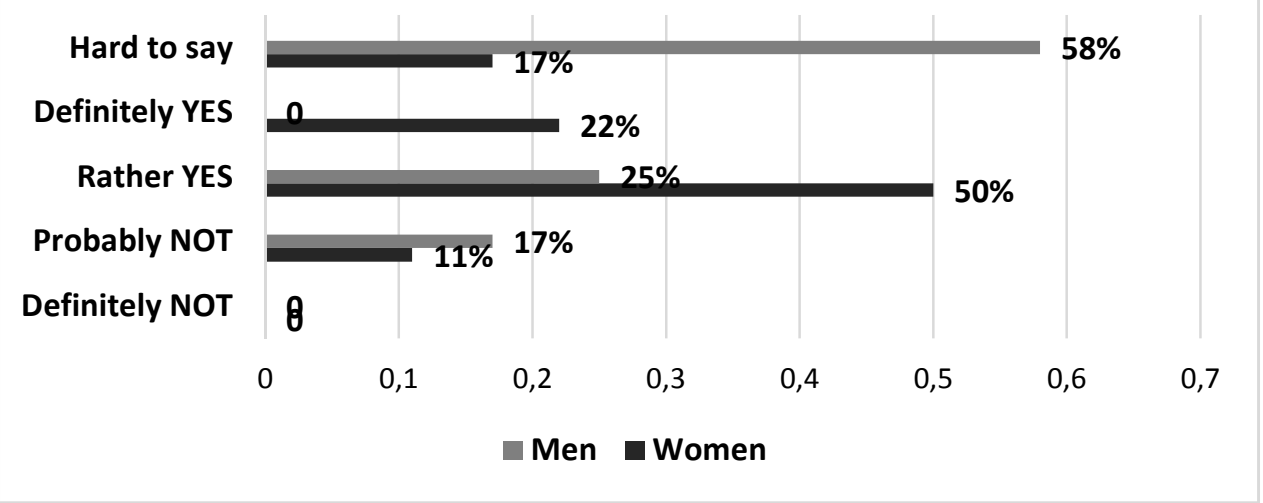

Chart 4. Declarations of purchasing products from socially engaged companies

Source: own research.

Respondents were asked how corporate social engagement affects their perception of companies, as well as their interest in the product of a given company and possible purchases. The variable was the respondents' gender. As much as $58 \%$ of men and $17 \%$ of women expressed their indecision in regards to a purchase declaration of a product from a socially engaged company. $50 \%$ of women and $25 \%$ of men were rather decided and $22 \%$ of women were determined to buy products from socially engaged companies while there was no such declaration among men. The answer 'rather not' was indicated by $17 \%$ of men and $11 \%$ of women. None of the respondents indicated the answer 'definitely not' in the examined question. On this basis, it can be concluded that women pay far more attention to companies that are socially involved and declare more often the purchase products from these companies. This result looks optimistic, although it must be remembered that this is only a declaration and in a real purchase situation this factor might have lower significance. 


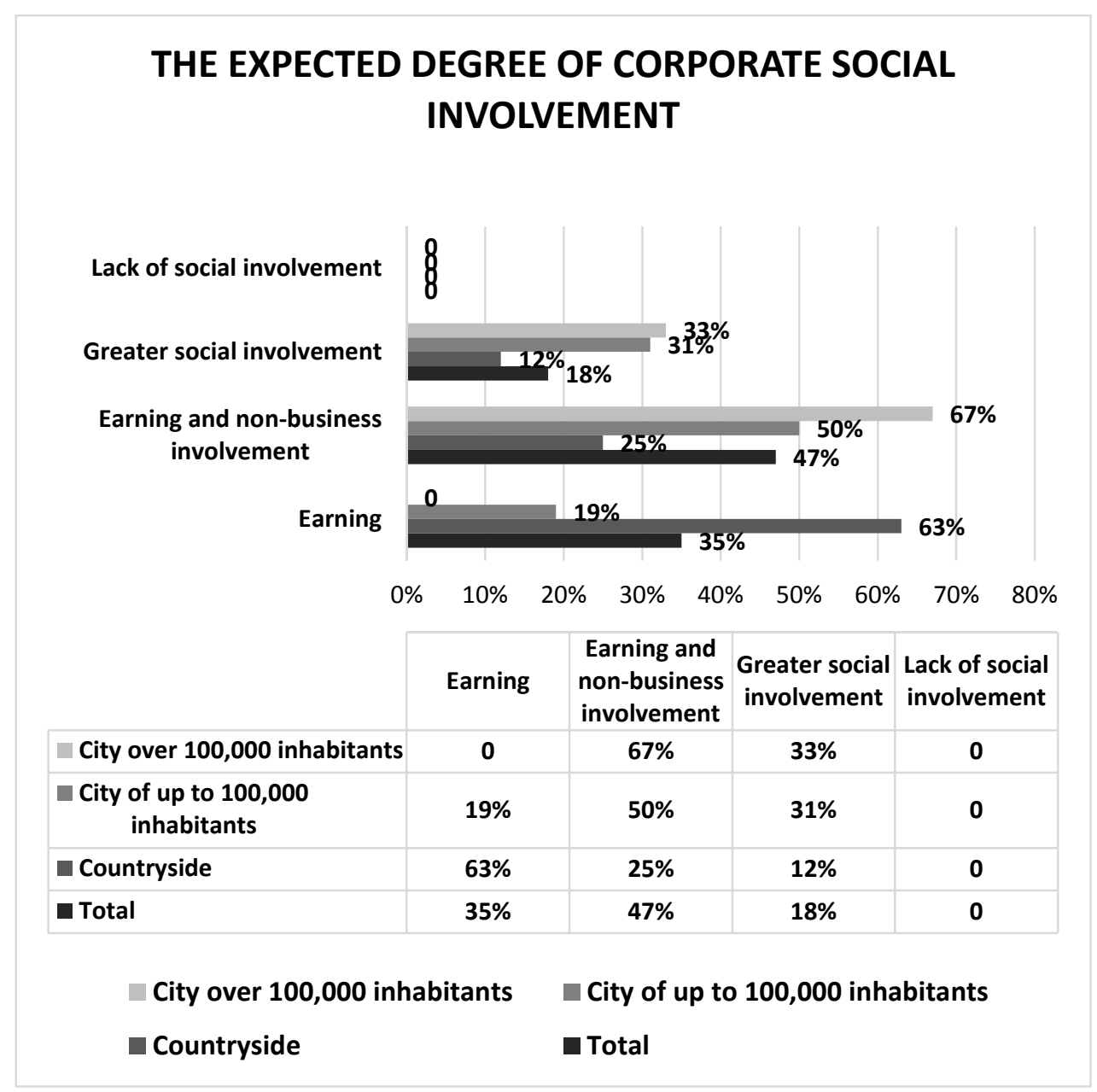

Chart 5. To what extent do the respondents expect social involvement from corporations?

Source: own research.

The respondents expect social involvement from companies. Upon request to indicate one main purpose of the existence of companies (out of 4 goals differing in the degree of social involvement), the majority of residents of cities with more than 100,000 inhabitants indicated that the goal of companies and enterprises should be earning money and noncommercial involvement at the same time (67\%). $63 \%$ of countryside residents believe that the goal of companies is earning money. None of the respondents expects any kind of involvement, and $47 \%$ of all respondents believe that earning money should be accompanied by some involvement in non-commercial activities. The rest, more than $30 \%$ of urban residents, and $18 \%$ of all respondents expect explicitly bigger engagement for society from corporations - active support of various types of activities and initiating them (not only responding to the demands of the environment). 


\section{CONCLUSIONS}

The concept of corporate social responsibility, which has recently gained popularity, is a voluntary decision, which means that there is no obligation on enterprises to carry out activities in this field. However, the current market conditions force them to look for new ways to gain a competitive advantage and thus increase the company's value.

Providing support for local communities, environmental protection, ethical code, proper care of the professional and personal development of employees - these ought to be the main activities within the boundaries of CSR. Despite the fact that such activities can be undertaken by all companies, the companies that do undertake them are mainly the large ones.

According to a report by a consulting company called KPMG, as well as Forum Odpowiedzialnego Biznesu, 96 per cent of companies in Poland are aware that the duty to undertake CSR activities lies on enterprises, however, only 46 per cent of them actually complies with it. Meanwhile, over 70 per cent of Poles are still not familiar with the concept of CSR.

To survive in the current market, a company should establish relationships with a wide array of stakeholders. Ignoring their voice in the process of designing and implementing activities within the area of social responsibility may result in the inadequate identification of social needs, inappropriate tools to respond to them, or lower efficiency. Therefore, it is worth to identify key stakeholders and establish a dialogue with them in order to take advantage of the potential benefits for the company and its social environment, which lies in a properly implemented strategy of corporate social responsibility.

Statistical data and customer behaviour surveys clearly demonstrate that characteristics related to Corporate Social Responsibility are becoming significant. The conclusion is obvious - companies which aim to meet market expectations will need to take into account the issues of corporate social responsibility while planning their strategies. Nowadays, CSR is not merely a matter of choice, but a necessity. The notion of responsible business has entered the language of the media, has become the object of public interest and, above all, has become a comprehensive concept of managing enterprises and for these reasons it cannot be ignored.

\section{REFERENCES}

Adamczyk, J. (2009). Społeczna odpowiedzialność przedsiębiorstw. Warszawa: PWE.

Bartkowiak, G. (2011). Społeczna odpowiedzialność biznesu w aspekcie teoretycznym i empirycznym. Warszawa: Difin.

Danielak, W. (2012). Kształtowanie kapitału relacyjnego w matym i średnim przedsiębiorstwie. Wrocław: Wyd. UE.

gap.uek.krakow.pl/images/dokumenty_sympozja/odpbiz.pdf (access: 20.01.2018).

Grudzewski, M., Hejduk, I.K., Sankowska, A., Wańtuchowicz, M. (2009). Zarzadzanie zaufaniem w przedsiębiorstwie. Koncepcja, narzędzia, zastosowania. Kraków: Oficyna Wolters Kluwer Polska.

Hąbek, P. (2010). Społeczna odpowiedzialność a zarządzanie jakością. Gliwice: Wydawnictwo Politechniki Śląskiej.

http://odpowiedzialnybiznes.pl/artykuly/zarzadzanie-relacje-z-interesariuszami-jako-jeden-zelementow-spolecznej-odpowiedzialnosci-biznesu/_access: 22.01.2018).

http://odpowiedzialnybiznes.pl/hasla-encyklopedii/interesariusze/ (access: 21.01.2018). 
Paliwoda-Matiolańska, A. (2014). Odpowiedzialność społeczna w procesie zarzadzania przedsiębiorstwem. Warszawa: Wydawnictwo C.H. Beck.

Rojek-Nowosielska, M. (2006). Kształtowanie społecznej odpowiedzialności przedsiębiorstw. Wrocław: AE.

Rok, B. (2008). Zarządzanie społeczna odpowiedzialnościa przedsiębiorstw, „Przegląd techniczny". Vol. 19.

Rok, B. (2012). Społeczna odpowiedzialność biznesu [in:] Gasparski, W., ed., Biznes, etyka, odpowiedzialność. Warszawa: WN PWN.

Roszkowska, P. (2011). Rewolucja w raportowaniu biznesowym. Interesariusze, konkurencyjność, spoteczna odpowiedzialność. Warszawa: Difin.

www.csr.szczecin.pl/baza-wiedzy/czym-jest-csr (access: 20.01.2018).

DOI: $10.7862 /$ rz.2019.mmr.8

The text was submitted to the editorial office: January 2019.

The text was accepted for publication: March 2019. 
